\title{
AL-A'RAF
}

Jurnal Pemikiran Islam dan Filsafat

\section{MENANGKAL ISLAMOFOBIA MELALUI RE-INTERPRETASI ALQUR'AN}

\author{
Abdul Aziz \\ Santri Alumni Pondok Pesantren Al-Huda, Kebumen.
}

\begin{abstract}
Abstrak
Keywords:

Islamofobia merupakan salah satu gejala kontemporer yang sangat

Islamophobia,

Radicalism,

Re-interpretation merisaukan. Ini memang bukan hal baru, tapi jika tidak segera diatasi tentu dapat memberikan efek negatif bagi kehidupan masyarakat. Bukan hanya bagi masyarakat Muslim, tapi juga nonMuslim. Tulisan ini mencoba menawarkan solusi dengan cara reinterpretasi Alqur'an. Dengan pendekatan sosio-historis melalui tafsir tematik, dengan terlebih dahulu mengumpulkan sebagian ayat Alqur'an yang berkaitan dengan de-islamofobia kemudian diinterpretasikan sesuai dengan asbâb al-nuzûl serta setting sosiohistoris turunnya ayat, kemudian disarikan dengan pemahaman mufassir yang dikontekstualisasikan dengan era kekinian. Karena Alqur'an telah menjelaskan bahwa Islam itu tidak seperti yang diyakini oleh para penganut islamofobia. Islam sangat menjunjung perdamaian dan toleransi.
\end{abstract}

\begin{abstract}
Islamophobia has been known as one of the contemporary issues which really raise concerns. It is not a new case indeed, however when it is not taken seriously in an attempt to solve it, it can give negative effect to people's life, not only for the Muslim, but also for the nonMuslims. This article tries to offer solution through the holy Qur'an's re-interpretation. Based on the socio-historical approach, by using thematic interpretation, by first collecting some of the Qur'anic's sentences related to the de-islamophobia then interpreted in accordance with asbâb al-nuzûl and its socio-historical setting followed by the Mufassir's understanding which is contextualized with today's context. Since the holy Qur'an has emphasized that Islam is not like what has been believed by the followers of the islamophobia. Islam highly upholds tolerance and peace.
\end{abstract}




\section{Pendahuluan}

Islam sebagai agama samawi yang diturunkan Tuhan kepada umat manusia di semesta ini pada prinsipnya mengandung perintah positif. Perintah positif yang ada dalam Islam sudah diyakini lebih dari XV abad yang lalu. ${ }^{1}$ Pada masa itu Allah SWT. menurunkan seorang Nabi dan Rasul terakhir, Muhammad Ibn 'Abdillâh. Nabi Muhammad SAW. pun dalam menyampaikan ayat-ayat kitâbullâh dengan metode atau cara yang rahmat (positif), sebagaimana Allah SW'T. ketika menyampaikan kalam-Nya di Alqur'an. Ayat-ayat dalam Alqur'an sendiri, jika diteliti dengan seksama, maka akan didapati ayat-ayat mengandung hal positif. Jika ada ayat-ayat yang 'berbau' negatif pun tidak lain hanyalah larangan (nahì) dari Allah, agar manusia tidak tersesat dari jalan yang lurus.

Metode nabi Muhammad SAW. dalam memperkenalkan Islam kepada penduduk Arab pada zaman itu merupakan contoh paling nyata, sekaligus paling utama bagi kalangan Muslim di dunia. Bahkan tidak hanya kaum Muslim, melainkan kaum non-Muslim pun dalam sejarahnya memang sudah menobatkan nabi Muhammad SAW. sebagai seorang manusia yang al-amin (dapat dipercaya dan tidak mungkin untuk berdusta). Artinya, nabi Muhammad SAW. sangatlah bijak dalam bersosial. ${ }^{2}$ Setelah

${ }^{1}$ Tentang hal ini, Lihat, M. Quraish Shihab, Membumikan Al-quran: Fungsi dan Peran Wabyu dalam Kehidupan Masyarakat (Bandung: Mizan, Cet. ke-XIII, 1996), 21, 100. Lihat, Alqur'an surat (15/Al-Hijr) ayat 9; QS. 14 ayat 1; Atau lihat, M. Quraish Shihab, Mukjizat Alquran: Ditinjau dari Aspek Kebahasaan, Isyarat Ilmiah, dan Pemberitaan Gaib (Bandung: Mizan, Edisi ke-II, 2013), 45-50, 60; Muhammad Sulaiman, Al-Burhân 'Ala Waby Alqur'an, diterjemahkan oleh Muhammad Habib M. dengan judul, Menyanggah Keraguan Terbadap Alqur an (Solo: Ramdhani, 1989), 11; Moenawar Kholil, Al-qur an dari Masa ke Masa (Solo: Ramdhani, Cet. ke-VII, 1994), 59; Abduddin Nata, Alqur an dan Hadits: Dirasah Islamiyyah I (Jakarta: RajaGrafindo Persada, Cet. ke-V, 1996), 59; Syahrin Harahap, Islam Dinamis: Menegakekan Nilai-Nilai Ajaran Alqur an dalam Kehidupan Modern di Indonesia (Yogyakarta; Tiara Wacana, 1997), 35.

${ }^{2}$ Sayyid Muhammad Ibn 'Alawî al-Mâlikî al-Hâânanî al-Makkî, Al-Qudwat alHasanah fî̀ Manhaj al-Da wah ilâ Allâh, diterjemahkan oleh Tim Editor dan Terjemah Hai ah Ash-Shofwah al-Malikiyyah dengan judul, Teladan Terbaik dalam Berdakwah (Surabaya: Yayasan Hai ah Ash-Shofwah al-Malikiyyah, 2014), 51. Untuk melihat metode 
nabi Muhammad SAW. wafat, maka tonggak kebenaran (shawât al-hâa, lisân al- $\underline{\text { haq }}$ ) ada pada diri sahabat-sahabatnya, kemudian diteruskan oleh tabi in, lalu tabi ut tabi in hingga sampai pada ‘uamâ (sebagai pewaris dari Nabi).

Ulama, sebagai pewaris kebenaran dari Nabi SAW. pada esensinya masih tidak terlepas dari prospek rencana awal dari misi Islam, yaitu dakwah. Islam mengajarkan berdakwah dengan cara yang hanif bukan cara jengis, mengedepankan rạmat bukan jahat, karena Islam merupakan agama yang menjunjung kasih sayang bagi semesta alam, bukan hanya untuk umat Islam saja. Oleh karenanya, wali-wali (para ulama) di Nusantara dalam berdakwah menyebarkan Islam di bumi Khatulistiwa ini pun menggunakan metode yang sopan dan beradab.

Dakwah multikultural, itulah yang barangkali seringkali didengar ketika membahas mengenai tata cara dakwah para ulama penyebar Islam di Indonesia. Walisongo misalnya, sebagai ulama yang dikenal kultural, adaptatif, dan akomodatif dalam menyebarkan kebenaran dîn al-Allâh di tanah Jawa ${ }^{3}$ (Indonesia) merupakan suri teladan bagi para da `i dan ulama (penerusnya) masa kini.

Islam Indonesia yang sedari dulu hidup damai, tenteram, dan harmonis, akhir-akhir ini mulai di sawur (baca: ditaburi) dengan debu-debu negatif, seperti radikalisme dan ekstrimisme, liberalisme dan sekularisme, hingga maraknya aliran-aliran (keislaman) yang telah melenceng dari ajaran Islam yang sesungguhnya (misalnya Gafatar, yang saat ini tengah ngetren). Sebut saja, isu-isu seperti Islamic State of Iraq and Syiria (ISIS) atau yang (ber-ideologi) semacam itu, yang menginginkan terbentuknya khilafah Islamiyyah. Walaupun menurut para ahli (agamawan, cendikiawan Muslim)

dakwah yang rahmat tersebut, lebih lanjut dapat dilihat, Sayyid Muhammad Nûh, Fiqhul Da wah al-Fardiyyah fì al-Manhaj al-Islamî, diterjemahkan oleh Ashfa Afkarina dengan judul, Da wah Fardiyah dalam Manhaj Amal Islam (Solo: Citra Islami Press, 1996), 69, 72; Atau lihat, Fathul Bahri An-Nabiry, Meniti Jalan Dakwah: Bekal Perjuangan Para Da i (Jakarta: Amzah, 2008), 115.

${ }^{3}$ Rosidi, Dakwah Multikultral di Indonesia: Studi Pemikiran dan Gerakan Dakwah Abdurrabman Wabid, dalam Jurnal Analisis, Vol. XIII, No. 2 (Desember 2015), 484-489; Wahyu Illahi dan Harjani Hefni, Pengantar Sejarah Dakwah (Jakarta: Kencana, 2007), 171. 
hal tersebut sangat sulit dilakukan, ataupun kalau hal itu bisa dilakukan haruslah menggunakan cara-cara yang rahmat (damai). Karena keinginan dari kelompok radikal ini belum juga terpenuhi, maka berbagai cara mereka lakukan demi mewujudkan "Islamic State", di manapun, sebagaimana di Indonesia. Bom Sarinah beberapa waktu lalu, juga dilakukan oleh para pelaku teroris (kelompok ekstrimis ISIS) yang menyebar di Indonesia. Bahkan dalam peristiwa ini, ISIS sendiri mengaku bertanggung jawab atas semua itu.

Hal tersebut di atas, tentu tidak hanya sebatas "isu-isu kontemporer" lagi, melainkan sudah melesat jauh menjadi "fakta-fakta (sejarah) kontemporer". Sebab aksi-aksi radikalisme yang mengatasnamakan agama di era sekarang ini akan menjadi salah satu sejarah kelam dari Islam. Sehingga, pantas saja kalau akhir-akhir ini ada isu "islamofobia", yakni sekelompok manusia yang anti dengan Islam, karena dalam pandangan mereka Islam itu adalah agama yang 'sangat menakutkan'.

Diakui atau tidak, islamofobia sangat berefek negatif, serta mencoreng citra damai Islam. Lebih dari itu, di beberapa wilayah seperti di Eropa dan Amerika, isu islamofobia ini telah membuat Islam tidak merasakan keadilan. Sebagaimana AM Saefuddin mengatakan bahwa efek islamofobia yang terjadi di belahan dunia itu:

"Diskriminasi dan ketidakadilan terhadap umat Islam di Barat bukanlah fenomena baru. Sudah lama umat Islam di negara-negara Eropa dan Amerika Serikat menjadi korban pelanggaran hak-hak asasi manusia." ${ }^{4}$

${ }^{4}$ Lihat, AM Saefuddin, Islamisasi Sains dan Kampus (Jakarta: PPA Consultants. 2010), 108. Ini akan terasa berbeda jika kehidupan yang dijalani oleh seorang nonMuslim di wilayah orang-orang Muslim. Dengan kelembutan dan kerahmatan Islam telah mengajarkan bagaimana menghargai kehidupan warga non-Muslim di wilayahnya. Pemerintah Islam telah mencoba menerapkan berbagai macam peaturan yang dapat mengakomodasikan kepentingan warga negara non-Muslim yang pada awalnya hanya hidup di daerah Islam atas perjanjian damai, hingga lama-kelamaan peraturan-peraturan tersebut pun dimasukkan sebagai hukum Islam. Demikianlah ajaran Islam yang sebenarnya. Islam bukan agama perang yang ditakuti, melainkan agama damai yang harus diikuti. Lengkapnya baca dalam, Majid Khadduri, Benarkah Islam Itu Agama Perang?: Memperbincangkan Hukum Perang dan Damai dalam Islam (Yogyakarta: Bina Media, 2005), 139-140. 
Indonesia, sebagai negara berpenduduk masyoritas Muslim, bahkan menjadi 'negara Muslim' terbesar di dunia, juga tidak boleh menyepelekan meledaknya paham islamofobia yang tengah berkembang. Boleh jadi, melencengnya kaum Muslim kepada aliranaliran pemikiran tertentu salah satunya disebabkan oleh pemikiran (salah paham) mereka dalam melihat Islam. Gafatar misalnya, yang akhir-akhir ini sudah difatwakan MUI sebagai aliran "sesat", menurut penulis merupakan pecahan dari agama Islam yang sudah dirasuki rasa ketidakpuasan mereka pada praktik-praktik dari ajaran Islam yang terkesan radikal. Maraknya aksi-aksi pengeboman, radikalisme, dan terorisme mengatasnamakan agama Islam, membuat mereka ingin membuat sekumpulan (religion pluralis community). Tidak ada kewajiban shalat dan semacamnya di sana, juga bentuk perilaku islamofobia yang boleh jadi dalam pikiran mereka shalat itu tidaklah penting. Yang terpenting dalam beragama adalah melaksanakan praktik yang berkemajuan (demi mewujudkan diri yang berintelektual dan berkarya). Tidak aneh jika dalam praktik-praktik keagamaannya, Gafatar lebih memajukan sistem pertanian dan semacamnya, dari pada praktik spiritual. Karena boleh jadi, mereka sudah dirasuki oleh kebencian dan ketidaksenangan dengan Islam.

Oleh karena itu, antara radikalisme, liberalisme, dan islamofobia ini merupakan hal yang sangat berkaitan. Pada perkembangannya, memang harus diwaspadai akan maraknya islamofobia. Untuk membendung virus perusak manis Islam tersebut, maka diperlukkan sebuah upaya penyadaran serta pemahaman kembali kepada publik tentang arti dari agama Islam itu sendiri, dalam arti yang sebenarnya. Namun, kebanyakan kalangan Muslim tidak begitu memperdulikan maraknya fenomena islamofobia ini. Padahal resikonya sangat merugikan umat Islam sendiri.

Melihat gencarnya isu islamofobia yang sudah menggerogoti citra manis Islam, di sinilah umat Islam, khususnya di Indonesia 
perlu menjelaskan kepada dunia bahwa Islam tidaklah menakutkan. Alqur'an sebagai pegangan dan referensi pokok umat Islam sangatlah dibutuhkan untuk menginterpretasikan kalam Tuhan mengenai Islam. ${ }^{5}$ Maka, pertanyaan yang perlu disampaikan di sini adalah; bagaimana solusi yang ditawarkan Islam—-melalui kitab sucinya Alqur'an—untuk menangkal fenomena islamofobia ini?

\section{Islamofobia sebagai Isu Kontemporer}

Islamofobia merupakan salah satu isu kontemporer yang sedang gencar. Tidak hanya di media-media Barat, melainkan juga tidak sedikit media di Indonesia yang meluncurkan berita mengenai islamofobia. Hal ini mengindikasikan bahwa di Indonesia pun sedang "siaga" akan adanya islamofobia.

Definisi islamofobia sendiri merupakan gabungan dari kata "Islam" dan "fobia". Islam sebagaimana yang telah diketahui, pada intinya merupakan agama samawi yang dalam ajarannya mengandung perintah dan larangan untuk menyekutukan selain dari pada Tuhan (Allah SWT.), mulai dari harus mengamalkan rukun Islam dan rukun iman. Sedangkan kata "fobia", berasal dari bahasa Inggris "phobia", yang berarti takut, benci. ${ }^{6}$ Dengan demikian, islamofobia adalah sebuah paham yang membenci dan takut kepada Islam. Takut tersebut, dikarenakan oleh banyak hal, misalnya Islam terkesan sebagai agama yang ekstrim, perang (jihad) dan hal-hal negatif lainnya. ${ }^{7}$

${ }^{5}$ Dalam pandangan Syafi i Maarif dan Harun Yahya, Alqur`an merupakan kitab yang sejalan dengan perkembangan zaman. Ia akan tetap digunakan serta diperlukan sebagai pencerah (budan) untuk memberikan solusi dari pelbagai problematika kehidupan umat manusia. Selengkapnya baca, Ahmad Syafi i Maarif, Alqur an dan Realitas Umat (Jakarta: Republika, 2010), h., 3; Harun Yahya, The Moral Values of the Qur'an, diterjemahkan oleh Ummu Azizah dengan judul, Nilai-Nilai Moral Alqur an Jakarta: Senayan Abadi Publishing, 2003), 56.

${ }^{6}$ KBBI Offline versi 1.5.1

${ }^{7}$ Mohammad H. Tamdgidi, "Beyond Islamophobia and Islamophilia as Western Epistemic Racisms: Revisiting Runnymede Trust's Definition in a World-History Context", Islamophobia Studies Journal, Vol. 1, No. 1 (2012), 57. 
Paham islamofobia biasanya beredar pada masyarakat (seseorang) yang minim akan imu pengetahuan agamanya. Karena mereka lebih banyak sudah dipengaruhi kehidupan yang bebas, liberal, dan memang kurang akan pengetahuan terhadap ajaran Islam yang sebenarnya. Oleh karenanya, kaum islamofobia biasanya lebih banyak didapati di negaranegara maju, seperti Eropa dan Amerika. Selain karena ketidaktahuan tentang makna dan ajaran Islam yang sebenarnya, tidak jarang juga memang karena adanya fanatisme agama. Seperti agama Kristen dan Yahudi yang sudah sedari awal membenci Islam. Tolak balik dari islamofobia ini adalah Islam radikal, yang juga muncul disebabkan adanya reaksi dari golongan islamofobia. ${ }^{8}$ Hingga dari kaum radikalis ini pun membenci negara-negara yang banyak mengadopsi pemikiran islamofobia tersebut, seperti Amerika dan semacamnya. ${ }^{?}$

Padahal, Islam sendiri tidaklah mengajarkan demikian. Islam sangat menganjurkan sikap keterbukaan, dialog, dan toleran dengan sesama umat manusia. Sebagaimana yang sudah dinyatakan dalam Q.S. al-Hujarat ayat 13:

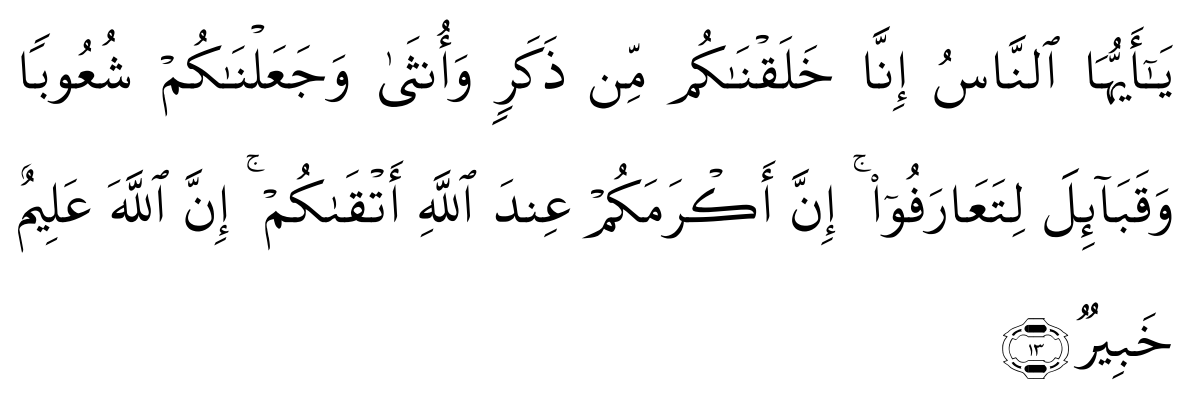

Hai manusia, sesungguhnya Kami menciptakan kamu dari seorang laki-laki dan seorang perempuan dan menjadikan kamu berbangsabangsa dan bersuku-suku supaya kamu saling kenal-mengenal. Sesungguhnya orang yang paling mulia di antara kamu di sisi Allah

${ }^{8}$ Wawancara pribadi dengan Syamsul Bakri, Surakarta, 14 April 2016. Ia merupakan seorang ahli sejarah kebudayaan Islam serta pengamat pergerakan-pergerakan Islam di Indonesia.

9 Etin Anwar, Hobart and William Smith Colleges, "The Dialectics of Islamophobia and Radicalism in Indonesia", ASLA Network Exchange, Vol. XVI, No. 2 (Spring 2009), 53. 
ialah orang yang paling taqwa di antara kamu. Sesungguhnya Allah Maha mengetahui lagi Maha Mengenal.

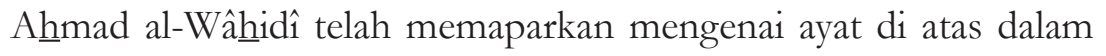
Asbâb al-Nuqû́l al-Qur ân-nya, melalui sanad Abû Hasân al-Muzakkî, ke atas hingga `Abd al-Jabâr Ibn al-Wardi al-Makkî, yang dikabarkan dari Ibn Abî Mulaikah, bahwa ketika Fath al-Makekah salah satu sahabat Nabi SAW. yang bernama Bilâl, naik ke atas Ka bah dan mengumandangkan adzan di sana. Lalu sebagian orang mengatakan:

"Wahai hamba Allah, apakah pantas seorang budak hitam mengumandangkan adzan di atas Ka`bah yang suci?”, Kemudian sebagian orang yang lain di antara mereka pun menuturkan: "jika Allah murka dengan orang ini, pasti lah Allah akan menggantinya." 10

Ayat di atas secara tersurat sudah dapat dipahami bahwa Allah SWTT. tidak memandang manusia dari suku, bangsa, dan budaya mana pun. Dalam bahasa Musa Asy`ari, tinggi rendahnya manusia di hadapan Tuhan tidak ditentukan oleh adanya realitas perbedaan dan pluralitas, tetapi oleh kadar ketaqwaannya. ${ }^{11} \mathrm{Hal}$ ini dengan melihat kata شُعُوبًا yang secara leksikal berarti sesuatu yang bercerai-berai atau bercabang. ${ }^{12}$ Dan oleh Ath-Thabranî melalui sanad shabîhb-nya dari al-Mujâhîd menjelaskan bahwa syu ûbâ berarti sesuatu yang serupa dan luas (berbangsa-bangsa). ${ }^{13}$ Sedangkan قَبَآِِل berarti berbagai golongan, ${ }^{14}$ atau dalam bahasa lainnya dipertegas deñgan kafilah; bersuku-suku. ${ }^{15}$

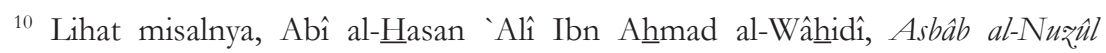
Alqur ân (Beirut: Dâr al-Kutub al-'Ilmiyyah, 1991), 411; juga lihat, Jalâl al-Dîn al-Sûyuthî, Lubâb al-Nuqûl fì Asbâb al-Nuqû̉l (Beirut: Dâr al-Fikr, 2002), 256.

${ }^{11}$ Musa Ays'ari, Dialektika Agama untuk Pembebasan Spiritual (Yogyakarta: LESFI, 2002), 112.

${ }^{12}$ Mahmud Yunus, Qâmûs 'Arabiyyu-Indûnisiyyu (Jakarta: Mahmud Yunus Wa Dzurriyyah, 2010), 198.

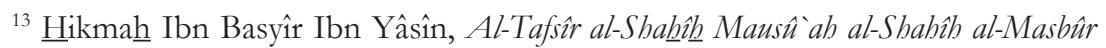
min al-Tafsîr bi al-Ma tsûr, Jilid 4 (Madinah: Dâr al-Mầtsar, 1998), 373.

${ }^{14}$ Mahmud Yunus, Qâmûs 'Arabiyyu-Indûnisiyyu...,. 330.

${ }^{15}$ Jalâl al-Dîn Muhahammad Ibn Aḥmad al-Mahallî dan Jalâl al-Dîn `Abd al-Raḥman 
Itu berarti, Tuhan sedari awal memang sudah menciptakan pluralitas manusia. Mulai dari Nabi Adam (golongan kaum laki-laki) dan Hawa (kaum perempuan), kemudian menjadikannya berbangsa-bangsa dan bersukusuku, bertujuan untuk لِتَعَارَفْو yaitu agar mereka saling membangun dan memperkuat saling pengertian dan tidak melihatnya hanya dalam perspektif tinggi dan rendah, ataupun baik dan buruk.

Tidak bisa dipungkiri bahwa dalam kehidupan masyarakat yang plural, seringkali ditemui ketidakadilan, kemiskinan, kebodohan, dan lemahnya hukum serta rendahnya disiplin masyarakat. Namun, Islam sangat menekankan sikap yang arif dan rendah hati dalam menghadapi dan memberlakukan adanya pluralitas. Sehingga, dapat dihindari adanya konflik sosial yang destruktif dan tidak terkendali, seperti yang terjadi di masyarakat akhir-akhir ini. ${ }^{16}$

Bahkan di ayat lain, seperti dalam Q.S. Ali- 'Imran ayat 159, Allah telah menjelaskan tentang kelembutan dari ajaran Islam yang sesungguhnya:

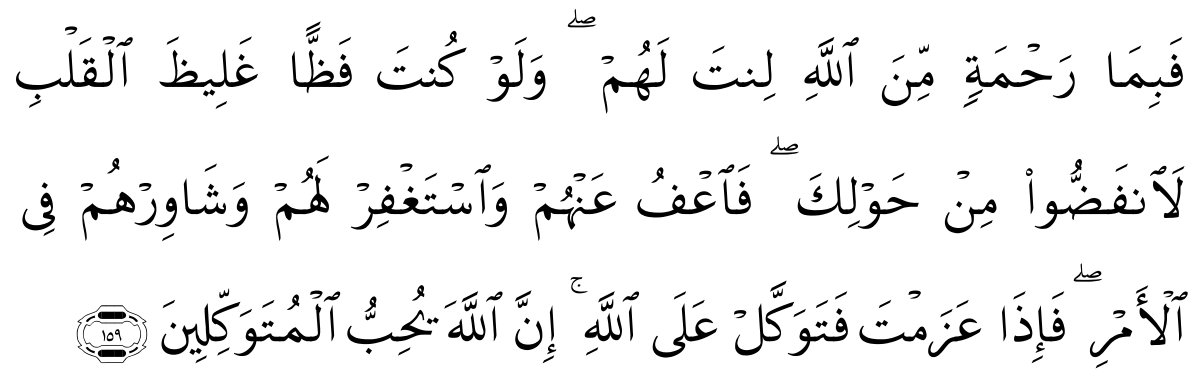

Maka disebabkan rahmat dari Allah-lah kamu berlaku lemah lembut terhadap mereka. Sekiranya kamu bersikap keras lagi berhati kasar, tentulah mereka menjauhkan diri dari sekelilingmu. karena itu ma'afkanlah mereka, mohonkanlah ampun bagi mereka, dan bermusyawaratlah dengan mereka dalam urusan itu. Kemudian apabila kamu telah membulatkan tekad, Maka bertawakkallah kepada Allah. Sesungguhnya Allah menyukai orang-orang yang bertawakkal kepada-Nya.

Abî Bakr al-Suyûthî, Tafsîr Alqur ân al-Karîm Li al-Imâmain al-Jalailain, Juz 2 (Surabaya: Al-Miftah), 186.

${ }^{16}$ Musa Ays'ari, Dialektika Agama untuk Pembebasan Spiritual..., 111. 
Ayat di atas, secara eksplisit memaparkan bahwa Allah sesungguhnya telah menyuruh kepada umat Muslim agar bersikap lemah-lembut terhadap orang lain. Jika melihat konteks di ayat sebelumnya, yaitu di ayat 156, di sana diterangkan bahwa Allah melarang kaum Muslim untuk menyamai orang-orang kafir (dari segi sikapnya yang arogan). Bahkan di ayat tersebut Allah seakan-akan menyanjung orang-orang Muslim dengan berfirman:

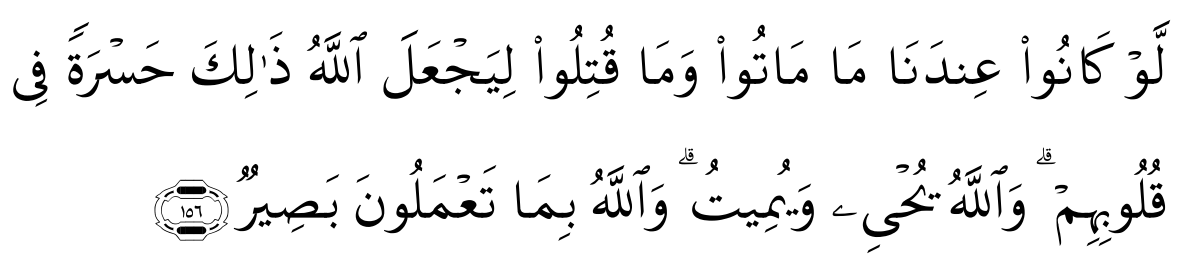

"Kalau mereka tetap bersama-sama kita tentulah mereka tidak mati dan tidak dibunuh." akibat (dari perkataan dan keyakinan mereka) yang demikian itu, Allah menimbulkan rasa penyesalan yang sangat di dalam hati mereka. Allah menghidupkan dan mematikan. dan Allah melihat apa yang kamu kerjakan.

Ayat tersebut merupakan bukti, sekaligus menjadi satu jawaban bahwa esensi dari gagasan-gagasan yang sebenarnya diberlakukan oleh Islam adalah gagasan yang penuh dengan kasih sayang, logis, terbuka, dan memberi kesempatan kepada yang lain untuk berpikir. Oleh sebab itu, apaapa yang disuguhkan media tentang islamofobia, sekiranya masih sangat perlu diklarifikasi dan dijustifikasi seakurat mungkin.

Di sisi lain, Alqur'an menyebut umat Islam sebagai umat terbaik yang akan menegakkan kebenaran dan menghalau kebatilan. Kebaikan tersebut diperoleh karena sifat moderat yang dimilikinya (ummatan wasathan). Inilah yang dibutuhkan dunia internasional saat ini. Walaupun harus diakui untuk mewujudkannya tidaklah mudah, dan itu harus dimulai dari diri sendiri. Sebagaimana yang dituturkan Muchlis Hanafi, bahwa sebuah perubahan masyarakat akan terwujud jika dimulai dari upaya memperbaiki diri sendiri, yakni dengan menerapkan sikap al-wasathiyyah dalam kehidupan seharihari. ${ }^{17}$

${ }^{17}$ Musa Ays'ari, Dialektika Agama untuk Pembebasan Spiritual..., 29. 
Itulah Islam yang sebenarnya. Kaum islamofobia seringkali mendistorsi dan memahami ajaran Islam di luar konteksnya. Itulah sebabnya mereka menjadi beringas dan arogan kepada Islam. Persatuan Bangsa-Bangsa (PBB) pernah menyeponsori sebuah seminar yang diadakan pada Februari 2005, dengan tema, Confronting Isalmophobia: Education for tolerance and Understunding (Melawan Ketakutan kepada Islam: Pendidikan untuk Toleransi dan Pemahaman). Kofi Annan, Sekjen PBB pada waktu itu mengakui ajaran dan prinsip Islam seringkali didistorsi dan dipahami di luar konteksnya. Sebagian orang mengklaim Islam tidak cocok dengan demokrasi serta menolak kemodernan dan hak-hak perempuan. Padahal, dunia Islam dan Barat di masa lalu saling bekerja sama dan saling memberikan pengaruh pada seni dan keilmuan. Jika para ilmuan Kristen tidak mendapatkan ajaran dan literatur Islam pada abad pertengahan dan masa-masa setelah itu, peradaban Eropa tidak akan mencapai kemajuan yang dimilikinya saat ini. ${ }^{18}$ Demikianlah sebagian kecil kontribusi dan sikap toleran Islam dengan penganut agama lain.

Kaum islamofobia, golongan yang membenci Islam ini banyak berletak di negara-negara Barat, walaupun kita tidak dapat memastikan kalau-kalau di Indonesia juga boleh jadi ada. Meluasnya islamofobia di negara Barat tidak lain, menurut AM Saefuddin adalah karena permainan politik para penguasa dan pemilik modal di Barat. Sarana terpenting yang digunakan oleh para penguasa dan kapitalisme Barat dalam menciptakan islamofobia adalah jaringan media massa Barat yang sangat efektif menciptakan atsmosfer ketakutan terhadap Islam di tengah masyarakat. Meskipun media massa Barat menguasai kecanggihan dan kemajuan teknologi informasi, namun menurut AM Saefuddin keterkaitan mereka kepada puncak-puncak kekuasaan dan keuangan membuat komitmen mereka untuk menampilkan kebenaran menjadi semakin menurun. Karena itu, menurutnya media-media Barat malah menjadi corong bagi

${ }^{18}$ AM Saefuddin, Islamisasi Sains dan Kampus..., 110. 
para politisi dan menampilkan Islam dengan wajah kasar dan ekstrim. ${ }^{19}$ Dengan demikian secara tidak langsung, masyarakat awam akan lebih condong untuk menganggap Islam sebagai agama yang kotor dan penuh dengan kekonyolan.

Hal ini tentu sangat berbahaya jika sampai tersebar ke pelosokpelosok daerah di Indonesia. Walaupun secara kuantitas, masyarakat Muslim Indonesia unggul, namun kita tidap dapat memungkiri jika secara kualitas sebagian Muslim di Indonesia, terutama di daerah-daerah pelosok masih haus akan pengetahuan yang dalam akan Islam. Oleh karenanya, kebanyakan dari mereka akan sangat mudah untuk terdoktrin. Baik doktrin menuju ekstrimisme, radikalisme, maupun liberalisme. Hingga suatu saat, boleh jadi mereka akan dengan mudah untuk meneguk paham islamofobia, sebagaimana yang terjadi di Barat.

Menurut penulis, maraknya aliran-aliran keagamaan yang baru-baru ini (ada dan terlahir) dalam perut bumi Nusantara, seperti Gerakan Fajar Nusantara (Gafatar) juga salah satu bentuk implementasi dari islamofobia. Mereka memahami agama, khususnya islam tidak seperti yang diinginkan. Kebanyakan dari mereka tidak jauh otak dan pemikirannya dengan kaum islamofobia di Barat. Untuk itu, salah satu faktor untuk meminimalisasi terjadinya islamofobia di Nusantara sendiri pada hakikatnya cukup mudah dan sangat dikenal, yaitu melaui pendidikan di pondok pesantren.

Pondok pesantren sebagai lembaga pendidikan tradisional di Indonesia merupakan alat yang sangat canggih untuk meredakan islamofobia. Kenapa islamofobia? Sikap ingin benar sendiri, egois, suka menyalahkan orang lain yang tidak sependapat dengan jalan pemikirannya, bahkan menuduh orang lain (temannya) sendiri telah keluar dari alur pemikiran yang benar, merupakan awal atau embrio terbentuknya sikap radikalisme (ektrimisme) dalam beragama. Setelah muncul radikalisme,

${ }^{19}$ Ibid., 112. Selain media massa, penerbitan buku-buku anti-Islam, misalnya buku karya Oriana Fallaci yang berjudul The Force of Reason dan lain-lain, menurut Saefuddin juga merupakan faktor lain yang menyebabkan meluasnya islamofobia. Lihat di halaman selanjutnya, 113. 
maka sikap umat lain memandangnya miring, bahkan telah dianggap beragama dengan kasar. Dengan demikian Islam tercoreng namanya, bahkan ajarannya. Jadi, ekstrimisme merupakan salah satu penyebab islamofobia.

Di sisi lain, liberalisme yang (juga) tengah berkembang di Indonesia merupakan kunci masuknya paham islamofobia dari sebelah kiri. Bagaimana tidak, jika seseorang sudah sangat sekuler, tidak terlalu memperdulikan akan (praktik) keagamaan, dan ia selalu hidup dengan damai, karena merasa tidak ada sesuatu yang membebani dalam hidupnya. Ia tidak begitu terberatkan dengan adanya perintah-perintah agama ataupun larangannya. Melainkan ia hidup dengan kehidupan yang tidak begitu memperdulikan ajaran agama. Ia hanya tahu hidup dengan kedamaian, bukan dengan kekejaman seperti perang dan sejenisnya. Nah, dengan demikian secara tidak langsung ia akan menjustifikasi seseorang yang dalam melakukan praktik keagamaan memakai cara yang tidak ia sukai, misalnya dengan mengebom, menteror dan hal-hal (dirasa) negatif lainnya. Dengan demikian, ia juga akan mudah untuk fobia (takut, benci, bahkan jijik) dengan agama (yang melakukan hal-hal yang tidak disukainya sebagaimana yang disebutkan tersebut). Liberalisme tindakan dan pikiran juga dipelopori dari rendahnya tingkat pendidikan yang baik kepada agama. Untuk itu, bagi masyarakat Muslim (Indonesia), pesantren sangat penting sekali sebagai gerbong 'pembasmi' liberalisasi dan radikalisasi. Sehingga virus islamofobia pun tidak dapat menyerangnya. Karena ia telah terbentengi dengan iman dan spiritual yang tinggi.

Karakteristik pesantren yang sejak dahulu lokasinya menyatu dengan masyarakat dengan tanpa dibatasi pagar dan para santri berbaur dengan masyarakat sekitar, merupakan model tepat dalam pencegahan (menangkal) islamofobia di Indonesia. Apalagi dewasa ini, isu pesantren sebagai sarang teroris pun cukup membuat kebakaran jenggot para kiai (ulama) di Indonesia. Khususnya ulama pesantren. Sebab hal itu pun tidak terbukti, justru sebaliknya pesantren sebagai lembaga pendidikan 
dan sosial kemasyarakatan tertua di Indonesia, adalah alat yang canggih dalam menangkal radikalisme mengatasnamakan agama. Selain memiliki pengaruh dan tidak terpisahkan dengan budaya, pesantren juga memiliki peran yang cukup dalam bidang sosial bahkan politik. ${ }^{20}$ Ini lah sebagian kecil kontribusi dari pada pesantren, sebagai lembaga pendidikan asli Nusantara (Indonesia).

Barangkali itulah kebanggaan tersendiri yang dimiliki (Islam) Indonesia, sehingga pada muktamar NU ke-33 Jombang beberapa waktu lalu, menjadikan tema "Islam Nusantara" sebagai topik dan agenda pokok dalam memperkukuh sikap lemah-lembut dan andap-asornya Islam di Indonesia. Ini sebagaimana yang dinyatakan Nasaruddin Umar, bahwa selama masih mengikuti manhaj Ablus Sunnah Wal Jama`ah yang selalu mengedepankan beberapa hal seperti, moderat (wasasthiyyah), toleransi (tasamubiyyah), reformis (islabiyyah), dinamis (tathawmuriyyab) dan metodologis (manhajizyah), niscaya kedamaian akan teteap terlaksana. Nah, konsep inilah yang kemudian disebut oleh Nasaruddin Umar, dengan konsep teologi inklusif. ${ }^{21}$

Dengan demikian, kaum islamofobia khusunya yang beredar di Indonesia, seharusnya memahami lebih dalam mengenai kearifan budaya dan Islam di Indonesia. Agar tidak semudah membalik telapak tangan dalam memandang Islam.

\section{De-islamphobia dalam Alqur'an}

Nabi Muhammad SAW. Menegaskan, "bahwa sesungguhnya aku tidaklah diutus Tuhan melainkan untuk menyempurnakan pekerti umat manusia”. Menanggapi Hadith ini, Musa Asy`ari menegaskan bahwa, budi pekerti merupakan tujuan utama dari agama yang dibawa Nabi

${ }^{20}$ Agus Salim Fatta, Pesantren Bukan Sarang Teroris: melawan Radikalisasi Agama (Jakarta: Pustaka Compas, 2010), 15 dan 6.

${ }^{21}$ Nasaruddin Umar, "Menggagas Islam Nusantara”, d FKMTHI Ulil Albab, edisi II (November 2015), 2. 
Muhammad SAW. yaitu Islam, sehingga dengan kemuliaan budi pekerti itu, kedatangan Islam dengan sendirinya dapat memberikan rahmat bagi kehidupan bersama. ${ }^{22}$

Banyak ayat-ayat Alqur'an yang membahas mengenai kehidupan islami (kehidupan yang positif). Dalam memahami ayat jihad pun misalnya, ketika mengatakan tentang ayat jihad dalam surat al-Taubah ayat 73 , harus ditafsirkan sesuai dengan konteksnya. Ayat berbicara tentang konteks jihad dan perang, jadi sudah sepantasnya bila nadanya keras dan tegas. ${ }^{23}$ Begitu pula ayat-ayat Alqur'an yang lain, harus diinterpretasikan sesuai dengan konteks dan metode yang tepat, agar tidak melenceng dari metodologi tafsir.

Islam menampilkan keharmonisan dan ketenteraman kehidupan yang sangat baik (positif) di akhirat nanti, jika manusia melakukan amal yang shaleh. Artinya, umat Islam yang beriman, tidak mengedepankan kekufuran, kejahilan dan kebringasan (ekstrim). Sebagaimana Thahir Muhammad Ibn Ya'qub al-Fîr Wazâbâdî, dalam menafsirkan orang-orang beriman dalam surat Al-basyr, yaitu mereka yang mengikuti nabi Muhammad SAW. dan Alqur'an atau kitâbullâh. ${ }^{24}$ Karena dengan jalan tersebutlah selama-lamanya seseorang tidak akan tersesat dan tidak akan melenceng dari kebenaran. Dengan memahami ayat-ayat Alqur'an secara mendalam dan kontekstual, maka akan mengetahui bagaimana ajaran Islam yang sebenarnya. Sehingga, islamofobia pun akan dapat tertangkalkan. Tidak mungkin seseorang yang memahami Islam dengan baik, dia akan terjangkit virus islamofobia.

${ }^{22}$ Musa Ays'ari, Dialektika Agama untuk Pembebasan Spiritual..., 86.

${ }^{23}$ Najih Ibrahim 'Abdullah, Naz̧harât fî haqấqatil isti'lâ'I bil-îmân, diterjemahkan oleh Zainal Abidin dengan judul, Membela Islam dengan Benar (Jakarta: BNPT dan The Nusa Institute, 2013), 43.

${ }^{24}$ Thahir Muhammad Ibn Ya'qub al-Fîr Wazâbâdî, Tanwîr al-Miqbâs Min Tafsîr Ibn 'Abbâs (Surabaya: Al-Hidayah, t.t.), 269. 


\section{Penutup}

Islamofobia sebagai sebuah isu kontemporer merupakan salah satu gejala yang sangat merisaukan. Media massa, baik di Barat maupun Indonesia tidak sedikit yang bertebaran menyoalnya. Ini sebenarnya bukan hal baru, namun jika tidak segera diatasi maka, akan benar-benar berbahaya bagi kelangsungan hidup masyarakat. Bukan hanya bagi masyarakat Muslim, melainkan juga bagi kaum non-Muslim.

Ayat-ayat Alqur'an secara mayoritas menerangkan, bahwa Islam adalah agama yang penuh dengan rahmat, ajarannya pun sangat bijak. Islam bukanlah seperti yang dibayangkan oleh para pelaku islamofobia. Apalagi Islam di Indonesia, yang bertebar kesantunan dan kesopanan. Islam pada hakikatnya mengutuk setiap perilaku teror dan radikalisme, juga tidak menerapkan perilaku liberalisme (sekularisme). Namun Islam merupakan agama yang ideal (moderat), inklusif, spritual, rasional dan sociality. Untuk itu, ayat Alqur'an dan Hadith-Hadith Nabi SAW. pun tidak menganjurkan umat Islam untuk berbuat hal-hal yang merugikan pihak lain. Dengan demikian, islamofobia di dunia dan yang sedang marak di media massa di Indonesia pun seyogyanya dapat diatasi dengan cara-cara yang baik dan damai.

Pesantren sebagai lembaga pendidikan Islam dan sosial kemasyarakatan di Indonesia merupakan salah satu alat pencegah maraknya islamofobia. Karena dengan hidup di pesantren, dapat terkader menjadi calon-calon kawula muda dan pemimpin masa depan yang baik. Pengajaran-pengajaran keilmuan Islam khususnya pemahaman akan makna Alqur`an dan Hadith Nabi yang tepat dengan pemahaman mayoritas ulama, merupakan arah yang jelas dalam mengembangkan Islam yang sesungguhnya, yaitu Islam yang rahmatan lil álamîn. 


\section{Referensi:}

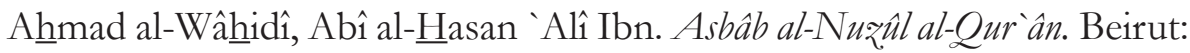
Dâr al-Kutub al-'Ilmiyyah, 1991.

Al-Sûyuthî, Jalâl al-Dîn. Lubâb al-Nuqûl fì Asbâb al-Nuðûl. Beirut: Dâr alFikr, 2002.

Ays'ari, Musa. Dialektika Agama untuk Pembebasan Spiritual. Yogyakarta: Lesfi, 2002.

Bahri An-Nabiry, Fathul. Meniti Jalan Dakwah: Bekal Perjuangan Para Da i. Jakarta: Amzah, 2008.

Basyîr Ibn Yâsîn,_Hikmah Ibn. Al-Tafsîr al-Shahîh Mausû̀ ah al-Shabîh alMasbûr min al-Tafsîr bi al-Ma `sûr, Jilid 4. Madinah: Dâr al-Mâ`tsar, 1998.

Etin Anwar, Hobart and William Smith Colleges. "The Dialectics of Islamophobia and Radikalism in Indonesia", ASIA Network Exchange, Vol. XVI, No. 2 (2009).

Fatta, Agus Salim. Pesantren Bukan Sarang Teroris: melawan Radikalisasi Agama. Jakarta: Pustaka Compas, 2010.

Harahap, Syahrin. Islam Dinamis: Menegakean Nilai-Nilai Ajaran Alqur'an dalam Kehidupan Modern di Indonesia. Yogyakarta; Tiara Wacana, 1997.

Ibrahim 'Abdullah, Najih. Ną̧harâtfî hạaqîaatil isti'lâ'I bil-îmân, diterjemahkan oleh Zainal Abidin dengan judul, Membela Islam dengan Benar. Jakarta: BNPT dan The Nusa Institute, 2013.

Jalâl al-Dîn Muhammad Ibn Ahmad al-Mahallî dan Jalâl al-Dîn ‘Abd alRahman Abî Bakr al-Suyûthî. Tafsîr al-Qur ân al-Karîm Li al-Imâmain al-jalailain, Juz 2. Surabaya: Al-Miftah, tt.

KBBI Offline versi 1.5.1

Khadduri, Majid. Benarkah Islam Itu Agama Perang?: Memperbincangkan Hukum Perang dan Damai dalam Islam. Yogyakarta: Bina Media, 2005.

Kholil, Moenawar. Alqur'an dari Masa ke Masa. Solo: Ramdhani, Cet. keVII, 1994.

Muchlis M. Hanafi. Moderasi Islam: Menangkal Radikalisme Berbasis Agama. Ciputat: Ikatan Alumni Al-Azhar dan Pusat Stud Alqur'an, 2013. 
Muhammad Ibn `Alawî al-Mâlikî al-Hââsanî al-Makkî, Sayyid. Al-Qudwat

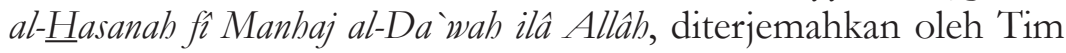
Editor dan Terjemah Hai ah Ash-Shofwah al-Malikiyyah dengan judul, Teladan Terbaik dalam Berdakwah. Surabaya: Yayasan Hai ah Ash-Shofwah al-Malikiyyah, 2014.

Muhammad Nûh , Sayyid. Fiqhul Da wah al-Fardiyyah fî al-Manhaj al-Islamî, diterjemahkan oleh Ashfa Afkarina dengan judul, Da wah Fardiyah dalam Manhaj Amal Islam. Solo: Citra Islami Press, 1996.

Nata, Abduddin. Alqur an dan Hadits: Dirasab Islamiyyah I. Jakarta: RajaGrafindo Persada, Cet. ke-V, 1996.

Quraish Shihab, M. Membumikan Alqur'an: Fungsi dan Peran Wabyu dalam Kehidupan Masyarakat. Bandung: Mizan, Cet. ke-XIII, 1996. . Mukjizat Alqur'an: Ditinjau dari Aspek Kebahasaan, Isyarat Ilmiah, dan Pemberitaan Gaib. Bandung: Mizan, Edisi ke-II, 2013.

Rosidi. "Dakwah Multikultral di Indonesia: Studi Pemikiran dan Gerakan Dakwah Abdurrahman Wahid", Analisis, Vol. XIII, No. 2 (2015).

Saefuddin, AM. Islamisasi Sains dan Kampus. Jakarta: PPA Consultants. 2010.

Sulaiman, Muhammad. Al-Burbân 'Ala Wahy Alqur'an, diterjemahkan oleh Muhammad Habib M. dengan judul, Menyanggah Keraguan Terbadap Alqur'an. Solo: Ramdhani, 1989.

Umar, Nasaruddin. "Menggagas Islam Nusantara”, FKMTHI Ulil Albab, edisi II (2015).

Syafi i Maarif, Ahmad. Alqur'an dan Realitas Umat. Jakarta: Republika, 2010. Tamdgidi, Mohammad H. "Beyond Islamophobia and Islamophilia as Western Epistemic Racisms: Revisiting Runnymede Trust's Definition in a World-History Context", Islamophobia Studies Journal, Vol. 1, No. 1 (2012).

Wahyu Illahi dan Harjani Hefni. Pengantar Sejarah Dakwah. Jakarta: Kencana, 2007.

Wawancara pribadi dengan Syamsul Bakri, Surakarta, 14 April 2016.

Yahya, Harun. The Moral Values of the Qur'an, diterjemahkan oleh Ummu Azizah dengan judul, Nilai-Nilai Moral Alqur'an. Jakarta: Senayan Abadi Publishing, 2003.

Ya'qub al-Fîr Wazâbâdî, Thahir Muhammad Ibn. Tanwîr al-Miqbâs Min Tafsîr Ibn 'Abbâs Surabaya: Al-Hidayah, t.t.

Yunus, Mahmud. Qâmûs `Arabiyyu-Indûnisiyyu. Jakarta: Mahmud Yunus Wa Dzurriyyah, 2010. 